\title{
Dikegulac-Sodium Sprays Stimulate Shoot Emergence in Asparagus Under Lathhouse Conditions
}

\author{
Sauveur Mahotiere', Clarence Johnson ${ }^{2}$, and Philamenia Howard ${ }^{3}$ \\ Agricultural Research Station, School of Agriculture, Home Economics \\ and Allied Programs, Fort Valley State College, Fort Valley, \\ GA 31030-3298
}

Additional index words. Asparagus officinalis, atrinal, apical dominance, correlative inhibition

Abstract. One-year-old greenhouse-grown 'Mary Washington', 'Emerald', 'UC 157 F,', and 'UC 157 F,' asparagus (Asparagus officinalis L.) seedlings were sprayed on 23 Sept. 1988 with dikegulac concentrations ranging from $O$ to $750 \mathrm{mg}^{-l i t e r}{ }^{-1}$ in 150 mg.liter ${ }^{-1}$ increments. No significant shoot emergence occurred before frost killed the ferns in December. With increasing temperature in Jan. and Feb. 1989, dikegulac promoted shoot emergence in all cultivars, except 'Mary Washington'. At 600 mg.liter ${ }^{-1}$ dikegulac had increased shoot emergence in 'Emerald', 'UC $157 \mathrm{~F}$,', and 'UC $157 \mathrm{~F}$;' by $310 \%, 161 \%$, and $305 \%$, respectively, over the control on 2 Feb. After frosts killed the first shoots, all cultivars responded to treatment as temperature increased. Dikegulac did not affect the height and dry weight of 'Mary Washington' ferns, but it reduced the height of 'Emerald' without affecting its dry weight. Both height and dry weight of ' $U C 157 F_{1}$ ' and ' $U C 157 F_{2}$ ' were reduced by the chemical. There was a significant effect of cultivar on shoot production regardless of treatment, but no significant cultivar $\times$ dikegulac interaction on shoot emergence. However, there were significant effects of cultivar and cultivar $\times$ dikegulac interaction on height and dry weight of the ferns. After the ferns had been cut off on 9 Aug. 1989, only 'UC $157 \mathrm{~F}_{1}$, and ' $U C 157 \mathrm{~F}_{2}$ ' showed increased shoot emergence. A second treatment of the plants with the chemical on 23 Sept. 1989 resulted in no significant increase in shoot emergence before or after freezing temperatures killed the ferns. Chemical name used: 2,3:4,6bis-0-(l-methyl ethylidene)-a-L-xylo-2 -hexulofuranosonic acid (dikegulac).

The capability of the apical meristem to inhibit the growth of lateral buds is common not only in aerial shoots but also in underground organs, including rhizomes, tubers, stolons, and corms of various plant species (Hillman, 1984; Phillips, 1969). Domination of the apical region over lateral buds is referred to as correlative inhibition (Brenner et al., 1987; Hillman, 1984; Martin, 1987). Asparagus rhizomes also exhibit this phenomenon, characterized by growth suppression of the proximal buds due to the presence of shoots on the crown. This effect results in a progressive emergence of spears during growth and harvest of the plant.

Dikegulac-sodium (Atrinal), a commercially available plant growth regulator, is effective in promoting branching in several plant species, including peach (Prunus persica) (Arnold et al., 1983), azalea (DeSilva et al., 1976), Columnea microphylla (Lyons and Hale, 1987), and pepper (Capsicum annuum) (Matta, 1984). Dikegulac also stimulated shoot emergence under greenhouse conditions, with some residual effects after

Received for publication 10 Apr. 1990. The cost of publishing this paper was defrayed in part by the payment of page charges. Under postal regulations, this paper therefore must be hereby marked advertisement solely to indicate this fact.

Professor of Horticulture.

${ }^{2}$ Associate Professor of Horticulture.

${ }^{3}$ Research Technician the 'Mary Washington' asparagus crowns had been soaked in $300 \mathrm{mg} \cdot$ liter $^{-1}$ or when the ferns were sprayed with 300 to $500 \mathrm{mg}$ of the compound/liter (Mahotiere et al., 1988, 1989). However, the effect of dikegulac on other asparagus cultivars has not been tested. Also unknown is the effect of exposure of the treated plants to freezing temperatures on the subsequent effectiveness of the chemical.

The objectives of this study were to determine growth and shoot emergence responses of four asparagus cultivars to dikegulac-sodium sprays under conditions simulating field temperatures and to assess further the residual effects of the chemical on the responses of these cultivars.

'Mary Washington', 'Emerald', 'UC 157 $\mathrm{F}_{1}$ ', and ' $\mathrm{UC} 157 \mathrm{~F}_{\mathrm{z}}$ ' asparagus seedlings were grown in 30-liter pots containing a ProMix medium consisting of 3 peatmoss : 1 perlite $: 1$ vermiculite (by volume). The medium, with an initial $\mathrm{pH}$ of 6.2 , was fertilized with ground limestone $\left(\mathrm{CaCO}_{3}\right)$ at $30 \mathrm{~g} /$ pot, which had raised the $\mathrm{pH}$ to 7.1 at the initiation of the dikegulac treatment. Then three seeds were planted per pot on 9 Sept. 1987; seedlings were thinned to one plant per pot. During the growing period, the plants were fertilized monthly with $10 \mathrm{~g}$ of $10 \mathrm{~N}-$ $4.5 \mathrm{P}-8.3 \mathrm{~K}$ formulation and watered regularly as needed. The day/night temperatures in the greenhouse were set at 25 and $15 \mathrm{C}$, respectively.

On 16 Aug. 1988, the plants were trans- ferred to the lathhouse to simulate temperatures in the field. The 1-year-old seedlings were treated with dikegtdac on 23 Sept. 1988. The number of shoots was recorded before spray application. Each potted plant was then sprayed to the drip point with the aqueous solutions of the dikegulac-sodium at the rates of $\mathrm{O}$ to $750 \mathrm{mg} \cdot \mathrm{liter}^{-1}$, at $150 \mathrm{-mg} \cdot$ liter $^{-1}$ increments. Tap water was used as the control solution. Each treatment was replicated 10 times, with one potted seedling as an experimental unit. The pots, set on the ground, were arranged in a split-plot design with cultivars as main plots and treatments as subplots.

By 22 Dec., the ferns were completely killed by freezing temperature. They then were cut at the soil level to prepare the pots for shoot emergence with the rise of soil and air temperatures. Spear emergence in the field starts in early March under normal weather conditions of central Georgia, where this study was conducted. However, the unusually high temperatures recorded in late December and early January triggered early emergence of shoots. Therefore, the first phase of data collection began in January.

Following killing of ferns by freezing temperatures (Phase 1). The unusually high temperature prevailed until the 2nd week of February. During that period, data on $\mathrm{cu}-$ mulative shoot emergence were recorded daily until subsequent frosts killed the ferns. These data are reported on a weekly basis. The frozen shoots were cut at the soil level. The intervening temperature increases in midFebruary promoted some insignificant emergence of shoots that subsequently were killed by frost. The emerged shoots were counted on a daily basis.

Following killing of first recorded shoots by freezing temperatures (Phase 2). In late February/early March and thereafter, the gradually rising temperatures triggered emergence of new shoots. Cumulative data on shoot number were recorded weekly from 3 Mar. through 7 Aug. 1989. The data are reported on a biweekly basis through 3 May. On' 8 Aug., the plants were cut at the soil level and the length and dry weight of the shoots were measured.

Following cutting off of ferns (Phase 3). Shoot emergence subsequent to removal of the ferns was recorded weekly, and the height of the plants was measured on 9 Sept. On 23 Sept. 1989, the plants received a second application of dikegulac using the same concentrations and methods as previously described. The number of shoots in each pot was recorded before the ferns were sprayed. Then data on cumulative number of new shoots were recorded weekly until freezing temperatures killed the ferns in late fall. In early Jan. 1990, the dead ferns were cut at the soil level.

Following killing of treated ferns by freezing temperatures (Phase 4). Increasing temperature from mid-January on triggered shoot emergence. The cumulative number of new shoots was recorded daily until 9 Feb. 1990, when the experiment was terminated. These data are reported on a weekly basis for 4 weeks. 
Table 1. Effect of dikegulac sprays on shoot emergence of asparagus seedlings after the ferns had been killed by low temperatures (Phase 1).

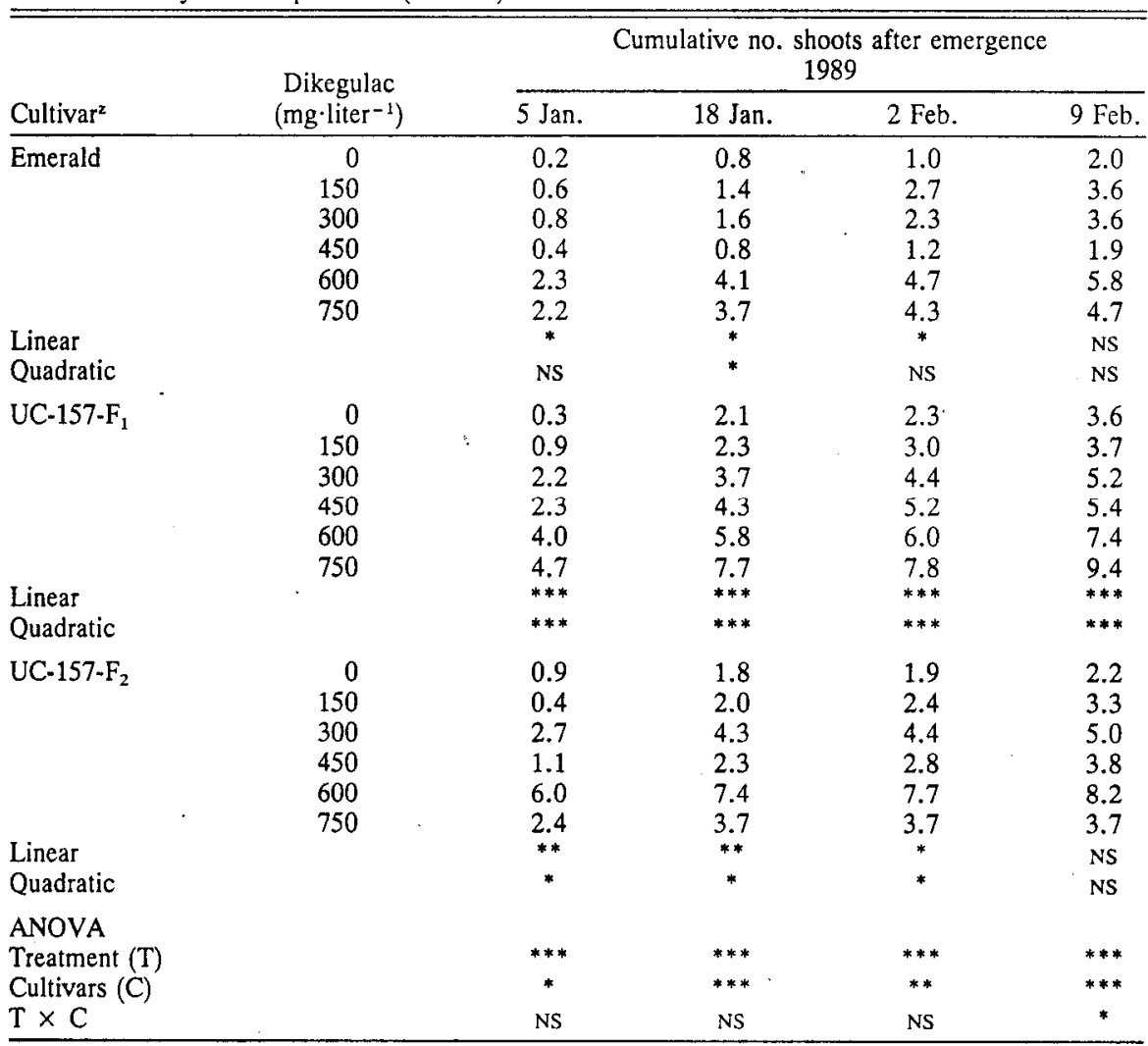

${ }^{z}$ Treatment had no significant effect on 'Mary Washington'.

NS.*.**.***Nonsignificant or significant at $P \leq 0.05,0.01$, or 0.001 , respectively.

Regression analysis and analysis of variance (ANOVA) were performed on all data.

Phase 1. Dikegulac promoted shoot emergence in all cultivars, except 'Mary Washington' (Table 1). The concentrations of 600 and $750 \mathrm{mg} \cdot$ liter- $^{1}$ were most effective. 'Emerald' and 'UC $157 \mathrm{~F}_{2}$ ' showed their highest response at $600 \mathrm{mg} \cdot$ liter $^{-1}$, whereas 'UC $157 \mathrm{~F}_{1}$ ' showed its highest response at $750 \mathrm{mg} \cdot$ liter $^{-1}$.

We previously reported that soaking 'Mary Washington' in $300 \mathrm{mg} \cdot \mathrm{liter}^{-1}$ or spraying the ferns with 300 to $500 \mathrm{mg}$ dikegulac/liter stimulated shoot emergence in greenhouse studies (Mahotiere et al., 1988, 1989). Yet, in Phase 1 of this experiment, 'Mary Washington' did riot respond to the treatments at the level of probability tested, although there was a trend for increased number of shoots at the $300-\mathrm{mg} \cdot$ liter $^{-1}$ rate. Early spear emergence has been positively correlated with the vigor of the asparagus plants (Ellison et al., 1960). Low vigor of 'Mary Washington' as compared to the other cultivars may have been responsible for the lack of response in Phase 1. The reverse would be true for the vigorous ' $\mathrm{UC} 157 \mathrm{~F}_{1}$ ', which responded in a highly significant manner in the first week of spear emergence.

As indicated by the lack of treatment $x$ cultivar interaction, the overall response of the cultivars to dikegulac was similar. However, there was a significant cultivar effect on shoot production, regardless of treatment. 'UC $157 \mathrm{~F}_{1}$ ' was the dominant shoot producer, followed in order by ' $\mathrm{UC} 157 \mathrm{~F}_{2}$ ',
'Emerald', and 'Mary Washington'. 'Mary Washington' and 'Emerald' are dioecious cultivars, whereas ' $\mathrm{UC} 157 \mathrm{~F}_{1}$ ' and 'UC 157 $\mathrm{F}$ ' are androecious. Male plants produced more spears than females or mixed cultivars (Corriols and Doré, 1989; Ellison et al., 1960; Franken, 1970). In field trials, 'UC $157 \mathrm{~F}_{1}$ ' produced higher yield and higher number of shoots per plant than most other cultivars (Hoult, 1987; Knaflewski, 1987). Therefore, its high shoot-producing ability displayed in this study is not surprising.

Phase 2. The sudden drop in temperature on 10 Feb. 1989 and the accompanying frosts killed the shoots produced in Phase 1 . The subsequent increase in temperature from 11 to $18 \mathrm{Feb} .1989$ triggered insignificant emergence of shoots, which were also destroyed by frost around $23 \mathrm{Feb}$. (data not shown). Therefore, Phase 2 of shoot emergence started in late Feb./early Mar. 1989. 'UC $157 \mathrm{~F}_{1}$ ' was the first to respond to the treatments, thus demonstrating again its superior vigor (Table 2). It was followed by 'Mary Washington', which had not responded in Phase 1 .

The cultivars differed in their growth response to the treatments (Table 2). In accordance with previous studies, dikegulac did not affect height and dry weight of 'Mary Washington' (Mahotiere et al., 1988, 1989). But, 600 and $750 \mathrm{mg} \cdot 1$ iter $^{-1}$ reduced the height of 'Emerald', 'UC $157 \mathrm{~F}_{1}$ ', and 'UC $157 \mathrm{~F}_{2}$ ' and the dry weight of ' $\mathrm{UC} 157 \mathrm{~F}_{1}$ ' and ' $\mathrm{UC} 157 \mathrm{~F}_{2}$ '.

In contrast to the response in shoot pro- duction, height of the cultivars did not differ significantly. However, cultivars showed different abilities to produce dry weight, regardless of treatment. 'UC $157 \mathrm{~F}_{1}$ ', which showed early and consistent shoot production response to the chemical in Phases 1 and 2 , accumulated the highest dry weight. Dry matter accumulation is a measure of plant growth. Therefore, these findings are consistent with the behavior of some cultivars, particularly ' $\mathrm{UC} 157 \mathrm{~F}_{1}$ ', with respect to early emergence and increased number of new shoots.

Phase 3. Contrary to their behavior in the previous phases, 'UC $157 \mathrm{~F}_{1}$ ' and 'UC 157 $\mathrm{F}_{2}$ ' did not respond early to the treatments in Phase 3. The number of shoots produced was also smaller than in Phases 1 and 2 . 'Mary Washington' and 'Emerald' did not respond at all, which explains the late-season treatment $\times$ cultivar interaction (Table 3 ).

The general lack of effectiveness of the chemical in this phase is not surprising. In a previous study, it also failed to stimulate shoot emergence in 'Mary Washington' in Phase 3 (Mahotiere et al., 1989). This result had been attributed to the end of the residual effects of the chemical or to the depletion of carbohydrate reserves in storage roots. But in this study, ' $\mathrm{UC} 157 \mathrm{~F}_{1}$ ' and ' $\mathrm{UC} 157 \mathrm{~F}_{2}$ ' showed some response to the chemical. In addition, as in Phase 2, dikegulac reduced height of ' $\mathrm{UC} 157 \mathrm{~F}_{1}$ ' and ' $\mathrm{UC} 157 \mathrm{~F}_{2}$ ' (Table 3 ). The effect of dikegulac in reducing plant height is well documented (Lyons and Hale, 1987; Malstrom and McMans, 1977; Schnall, 1978). However, different patterns of height responses to dikegulac, including no response at all, were noted among six cultivars of kalanchoe (Nightingale et al., 1985). Therefore, the reduction of height by the chemical in half of the cultivars casts doubt about the end of its residual effect. Also, even 'UC $157 F_{1}$ ', which showed an early and strong response to the chemical in the previous phases (Tables 1 and 2), showed a late and weak response to the chemical in Phase 3. Asparagus plants produce and store carbohydrates for spear production and fern growth in the following year (Scott et al., 1939). But, the length of harvest also decreases soluble carbohydrates in the storage roots (Sanders, 1985; Shelton and Lacy, 1988). Carbohydrates also decrease in the roots during the early stage of fern growth and start increasing during fern maturation, reaching a maximum after the stalks reach maturity (Shelton and Lacy, 1980). Similarly, in this study, the killing of emerged shoots by frost around 9 and $23 \mathrm{Feb}$. and the cutting of the stalks in summer, before they may have reached maturity, may have contributed to the depletion of carbohydrate reserves in the storage roots.

Phase 4. In contrast to the effectiveness of dikegulac in the previous phases, the second application of the chemical promoted no significant increase of shoot emergence in any of the cultivars tested (data not shown). Also, cultivar differences in shoot production disappeared.

Even 'UC $157 \mathrm{~F}_{1}$ ' and 'UC $157 \mathrm{~F}_{2}$ ', which 
Table 2. Residual effect of dikegulac sprays on shoot emergence after the previous shoots had been killed by freezing temperature(Phase 2).

\begin{tabular}{|c|c|c|c|c|c|c|c|c|}
\hline \multirow[b]{2}{*}{ Cultivar } & \multirow[b]{2}{*}{$\begin{array}{c}\text { Dikegulac } \\
\left(\mathrm{mg} \cdot \text { liter }^{-1}\right)\end{array}$} & \multicolumn{5}{|c|}{$\begin{array}{c}\text { Cumulative no. of shoots after emergence } \\
1989\end{array}$} & \multicolumn{2}{|c|}{$\begin{array}{c}\text { Terminal } \\
\text { shoot growth }\end{array}$} \\
\hline & & 7 Mar. & 21 Mar. & 4 Apr. & 18 Apr. & 3 May & $\begin{array}{c}\mathrm{Ht} \\
(\mathrm{cm})\end{array}$ & $\begin{array}{l}\text { Dry wt } \\
\text { (g) }\end{array}$ \\
\hline Mary Washington & $\begin{array}{r}0 \\
150 \\
300 \\
450 \\
600 \\
750\end{array}$ & $\begin{array}{l}1.2 \\
1.8 \\
3.8 \\
2.9 \\
2.0 \\
1.6\end{array}$ & $\begin{array}{l}4.1 \\
6.2 \\
7.8 \\
6.7 \\
6.3 \\
7.8\end{array}$ & $\begin{array}{l}4.4 \\
6.7 \\
8.6 \\
7.6 \\
6.8 \\
8.4\end{array}$ & $\begin{array}{l}4.6 \\
6.8 \\
8.6 \\
7.9 \\
7.2 \\
8.9\end{array}$ & $\begin{array}{r}4.7 \\
7.6 \\
9.2 \\
8.4 \\
7.7 \\
10.1\end{array}$ & $\begin{array}{l}153 \\
208 \\
161 \\
183 \\
171 \\
169\end{array}$ & $\begin{array}{l}58.3 \\
81.3 \\
53.3 \\
68.1 \\
68.2 \\
61.3\end{array}$ \\
\hline $\begin{array}{l}\text { Linear } \\
\text { Quadratic }\end{array}$ & & $\begin{array}{l}\text { NS } \\
\text { NS }\end{array}$ & NS & NS & $\stackrel{*}{*}$ & $* *$ & $\begin{array}{l}\text { NS } \\
\text { NS }\end{array}$ & $\begin{array}{l}\text { NS } \\
\text { NS }\end{array}$ \\
\hline Emerald & $\begin{array}{r}0 \\
150 \\
300 \\
450 \\
600 \\
750\end{array}$ & $\begin{array}{l}1.6 \\
1.9 \\
1.6 \\
2.0 \\
2.9 \\
1.7\end{array}$ & $\begin{array}{l}5.2 \\
6.1 \\
5.2 \\
5.6 \\
8.6 \\
6.0\end{array}$ & $\begin{array}{l}6.0 \\
6.9 \\
5.7 \\
5.6 \\
9.4 \\
7.2\end{array}$ & $\begin{array}{r}6.2 \\
6.1 \\
6.2 \\
6.3 \\
10.2 \\
7.7\end{array}$ & $\begin{array}{r}7.1 \\
6.7 \\
7.8 \\
6.8 \\
13.9 \\
9.1\end{array}$ & $\begin{array}{l}190 \\
181 \\
173 \\
187 \\
144 \\
170\end{array}$ & $\begin{array}{l}78.0 \\
76.2 \\
74.3 \\
78.0 \\
60.8 \\
72.8\end{array}$ \\
\hline $\begin{array}{l}\text { Linear } \\
\text { Quadratic }\end{array}$ & & $\begin{array}{l}\text { NS } \\
\text { NS }\end{array}$ & $\begin{array}{l}\text { NS } \\
\text { NS }\end{array}$ & $\begin{array}{l}\text { NS } \\
\text { NS }\end{array}$ & $\stackrel{*}{*}$ & $\begin{array}{l}* * \\
* *\end{array}$ & NS & $\begin{array}{l}\text { NS } \\
\text { NS }\end{array}$ \\
\hline$U C-157 \cdot F_{1}$ & $\begin{array}{r}0 \\
150 \\
300 \\
450 \\
600 \\
750\end{array}$ & $\begin{array}{l}2.4 \\
1.9 \\
2.4 \\
2.9 \\
2.1 \\
0.6\end{array}$ & $\begin{array}{r}6.0 \\
5.6 \\
6.7 \\
8.6 \\
9.8 \\
10.4\end{array}$ & $\begin{array}{r}6.9 \\
6.1 \\
8.7 \\
10.0 \\
10.2 \\
12.7\end{array}$ & $\begin{array}{r}7.0 \\
6.3 \\
8.9 \\
10.6 \\
10.2 \\
13.0\end{array}$ & $\begin{array}{r}7.9 \\
7.6 \\
9.6 \\
11.2 \\
10.1 \\
16.2\end{array}$ & $\begin{array}{l}201 \\
187 \\
182 \\
170 \\
170 \\
150\end{array}$ & $\begin{array}{l}95.2 \\
81.4 \\
78.9 \\
80.1 \\
80.1 \\
78.6\end{array}$ \\
\hline $\begin{array}{l}\text { Linear } \\
\text { Quadratic }\end{array}$ & & $* *$ & $* * * *$ & $* * *$ & $* * * *$ & $* * * *$ & $* * * *$ & $* * *$ \\
\hline UC- $157-F_{2}$ & $\begin{array}{r}0 \\
150 \\
300 \\
450 \\
600 \\
750\end{array}$ & $\begin{array}{l}1.6 \\
2.3 \\
1.3 \\
2.0 \\
2.1 \\
0.7\end{array}$ & $\begin{array}{l}3.7 \\
3.7 \\
5.8 \\
5.2 \\
7.8 \\
5.3\end{array}$ & $\begin{array}{l}4.1 \\
6.2 \\
6.4 \\
6.3 \\
8.4 \\
6.8\end{array}$ & $\begin{array}{l}4.2 \\
6.2 \\
6.7 \\
6.6 \\
9.3 \\
7.7\end{array}$ & $\begin{array}{l}4.9 \\
6.3 \\
7.3 \\
6.7 \\
9.7 \\
9.6\end{array}$ & $\begin{array}{l}171 \\
168 \\
175 \\
175 \\
161 \\
139\end{array}$ & $\begin{array}{l}72.6 \\
80.3 \\
79.3 \\
82.9 \\
59.8 \\
38.6\end{array}$ \\
\hline $\begin{array}{l}\text { Linear } \\
\text { Quadratic }\end{array}$ & & $\begin{array}{l}\text { NS } \\
\text { NS }\end{array}$ & $\begin{array}{l}\text { NS } \\
\text { NS }\end{array}$ & $\stackrel{*}{*}$ & $* *$ & ** & $* *$ & $* * *$ \\
\hline $\begin{array}{l}\text { ANOVA } \\
\text { Trcatment }(\mathrm{T}) \\
\text { Cultivars }(\mathrm{C}) \\
\mathrm{T} \times \mathrm{C}\end{array}$ & & $\begin{array}{l}\text { NS } \\
\text { ** } \\
\text { NS }\end{array}$ & $\begin{array}{l}* * * \\
* * * \\
\text { NS }\end{array}$ & $\begin{array}{l}* * * \\
* * * \\
\text { NS }\end{array}$ & $\begin{array}{l}* * * \\
* * * \\
\text { NS }\end{array}$ & $\begin{array}{l}* * * \\
* * * \\
\text { NS }\end{array}$ & $\begin{array}{l}* * * \\
\text { NS } \\
* * *\end{array}$ & $\begin{array}{c}* * * \\
* * * \\
* *\end{array}$ \\
\hline
\end{tabular}

NS,*,**,***Nonsignificant or significant at $P \leq 0.05,0.01$, or 0.001 , respectively.

Table 3. Residual effect of dikegulac sprays on shoot emergence after the previous shoots had been cut (Phase 3).

\begin{tabular}{|c|c|c|c|c|c|c|c|}
\hline \multirow[b]{2}{*}{ Cultivar $^{2}$} & \multirow{2}{*}{$\begin{array}{l}\text { Dikegulac } \\
\left(\mathrm{mg} \cdot \mathrm{liter}^{-1}\right)\end{array}$} & \multicolumn{5}{|c|}{$\begin{array}{l}\text { Cumulative no. of shoots after emergence } \\
1989\end{array}$} & \multirow{2}{*}{$\begin{array}{c}\begin{array}{c}\text { Terminal } \\
\text { shoot growth }\end{array} \\
\begin{array}{c}\mathrm{Ht} \\
(\mathrm{cm})\end{array}\end{array}$} \\
\hline & & 14 Aug. & 22 Aug. & 29 Aug. & 6 Sept. & 13 Sept. & \\
\hline UC-157-F & $\begin{array}{r}0 \\
150 \\
300 \\
450 \\
600 \\
750\end{array}$ & $\begin{array}{l}3.3 \\
3.2 \\
3.8 \\
3.7 \\
3.1 \\
5.9\end{array}$ & $\begin{array}{l}5.4 \\
5.11 \\
8.0 \\
7.3 \\
6.4 \\
6.7\end{array}$ & $\begin{array}{l}7.2 \\
5.9 \\
9.8 \\
9.8 \\
7.2 \\
8.0\end{array}$ & $\begin{array}{r}8.5 \\
6.7 \\
12.0 \\
11.4 \\
9.2 \\
10.8\end{array}$ & $\begin{array}{c}10.4 \\
7.7 \\
15.43 \\
14.0 \\
12.8 \\
13.0\end{array}$ & $\begin{array}{l}199 \\
196 \\
173 \\
186 \\
178 \\
161\end{array}$ \\
\hline $\begin{array}{l}\text { Linear } \\
\text { Quadratic }\end{array}$ & & $\begin{array}{l}\text { NS } \\
\text { NS }\end{array}$ & $\begin{array}{l}\text { NS } \\
\text { NS }\end{array}$ & $\begin{array}{l}\text { NS } \\
\text { NS }\end{array}$ & ${ }^{* *}$ & $*$ & $\begin{array}{l}* * * \\
* *\end{array}$ \\
\hline$U C-157-F_{2}$ & $\begin{array}{r}0 \\
150 \\
300 \\
450 \\
600 \\
750\end{array}$ & $\begin{array}{l}2.0 \\
3.1 \\
2.0 \\
1.6 \\
1.4 \\
1.0\end{array}$ & $\begin{array}{l}5.1 \\
5.3 \\
5.2 \\
5.4 \\
4.8 \\
2.9\end{array}$ & $\begin{array}{l}5.4 \\
6.6 \\
6.3 \\
7.3 \\
6.6 \\
3.7\end{array}$ & $\begin{array}{l}8.0 \\
7.8 \\
8.2 \\
9.3 \\
7.9 \\
5.3\end{array}$ & $\begin{array}{r}10.8 \\
10.0 \\
9.6 \\
11.8 \\
10.3 \\
5.8\end{array}$ & $\begin{array}{r}158 \\
184 \\
157 \\
177 \\
146 \\
92\end{array}$ \\
\hline $\begin{array}{l}\text { Linear } \\
\text { Quadratic } \\
\text { ANOVA }\end{array}$ & & $\begin{array}{l}\text { NS } \\
\text { NS }\end{array}$ & NS & $\begin{array}{l}\text { NS } \\
* *\end{array}$ & $\begin{array}{l}\text { NS } \\
\text { NS }\end{array}$ & $\begin{array}{l}\text { NS } \\
\text { NS }\end{array}$ & $\stackrel{*}{* * *}$ \\
\hline $\begin{array}{l}\text { Treatment }(T) \\
\text { Cultivars }(C)\end{array}$ & & $\begin{array}{l}\text { NS } \\
* * *\end{array}$ & $\begin{array}{l}\text { NS } \\
* * *\end{array}$ & NS & $\stackrel{+25}{*}$ & $\begin{array}{c}\text { NS } \\
*\end{array}$ & *** \\
\hline$T \times C$ & & NS & NS & NS & $* *$ & $* *$ & $*$ \\
\hline
\end{tabular}

'Treatment had no significant effect on 'Mary Washington' or 'Emerald'.

NS.*.**.***Nonsignificant or significant at $P \leq 0.05,0.01$, or 0.001 , respectively. consistently responded to the chemical in the three previous phases, failed to respond in Phase 4. The most potent responses to the chemical, as measured by percent increase of shoots over the controls and shoot number, were obtained in Phases 1 and 2 for all cultivars. For example, at $750 \mathrm{mg} \cdot$ liter $^{-1}$ 'UC $157 \mathrm{~F}_{1}$ ' had 9.4, 16.2, and 13.0 shoots/ plant at the end of Phases 1, 2, and 3, respectively, while the controls had 3.6, 7.9, and 10.4 (Tables 1-3). These data suggest that, particularly in phases 1 and 2, the control plants, in producing fewer shoots, would have used less carbohydrates or fewer buds for shoot emergence. Thus, contrary to the treated plants, they were able to produce shoots at a normal and progressive rate during the course of the experiment. A preliminary study also indicated that $500 \mathrm{mg}$ dikegulac/liter was more effective in stimulating shoot emergence in 2-year-old than 1year-old crowns (Mahotiere et al., 1988). In light of this evidence, plant age is an unlikely explanation for this lack of response. These results cannot be attributed to temperatures "either, for the temperatures in Jan. and Feb. 1990 were higher and more consistent than in 1989 (data not shown). Presumably, at the time of the second treatment, the stalks had not reached physiological maturity, which, as demonstrated by Shelton and Lacy (1980), coincides with the maximum carbohydrate level in the storage roots. Reduction in number of buds resulting from increased shoot emergence recorded in the previous phases is a possible explanation. Lack of effectiveness of dikegulac application in Phase 4 can be more plausibly explained by depletion of the plants than by termination of the residual effect of the chemical, a hypothesis that needs testing.

In conclusion, after freezing temperatures killed the ferns, dikegulac-sodium stimulated shoot emergence in all four asparagus cultivars tested, with lasting residual effects. If substantiated by field investigations, simultaneous and abundant spear emergence would reduce the number of passes in the field, thus shortening the harvest season and increasing early yields when prices are high.

\section{Literature Cited}

Arnold, C. E., J.H. Aldrich, and F.G. Martin. 1983. Peach response to dikegulac. HortScience 18:474-476.

Brenner, N. L., D.J. Wolley, V. Sjut, and D. Salermo. 1987. Analysis of apical dominance in relation to IAA transport. HortScience 22:833835.

Corriols, L. and C. Doré. 1989. Use of rank indexing for comparative evaluation of all-male and other hybrid types in asparagus. J. Amer. Soc. Hort. Sci. 114:328-332.

DeSilva, W. H., P.F. Bocion, and H.R, Walther. 1976. Chemical pinching of azaleas with dikegulac. HortScience 11:567-570.

Ellison, J. H., D.F. Scheer, and J.J. Wagner. 1960. Asparagus yield as related to plant vigor, earliness and sex. Proc. Amer. Soc. Hort. Sci. 75:411-415.

Franken, A.A. 1970. Sex characteristics and inheritance of sex in asparagus (Asparagus officinalis.L.) Euphytica 19:227-287.

Hillman, J.R. 1984. Apical dominance, p. 126- 
148. In: M.B. Wilkins (cd.). Advanced plant physiology. Longman Scientific and Technical/ John Wiley, New York.

Hoult, M.D. 1987. Asparagus cultivar trial, central Australia. Asparagus Res. Nwsl. 5:24-31.

Knaflewski, M. 1987. International asparagus cultivar trial. Asparagus Res. Nwsl. 6:27.

Lyons, R.E. and C.L. Hale. 1987. Comparison of pinching methods on selected species of Columnea, Kalanchoe, and Crassula. HortScience 22:72-74.

Mahotiere, S., C. Johnson, and P. Cullers. 1988. Asparagus crowns response to dikegulac. HortScience 23:308-309.

Mahotiere, S.,.C. Johnson, and P. Howard. 1989. Influence of dikegulac sprays on shoot emergence and growth of asparagus. HortScience
24:468-469.

Malstrom, H.L. and J.L. McMans. 1977. A chemical method of pruning young pecans trees. HortScience 12:68-69.

Martin, G. 1987. Apical dominance. HortScience 22;824-833.

Matta, F.B. 1984. Effects of hand-pinching and dikegulac sprays on Capsicum annuum. HortScience 19:284-285.

Nightingale, A. E., S.E. Cross, and M.T. Longnecker. 1985. Dikegulac alters growth and flowering of kalanchoe. HortScience 20:722724.

Phillips, D.J. 1969. Apical dominance in physiology of plant growth and development, p. 163402. In: M.B. Wilkins (cd.). Physiology of plant growth and development. McGraw-Hill, New York.
Sanders, D.C. 1985. Influence of extended harvest duration on carbohydrates accumulation and yield of established asparagus, p. 333-337. In: E.C. Lougheed and H. Tiessen (eds.). Proc. Sixth Intl. Asparagus Symp., Univ. of Guelph, Canada.

Schnall, R.A. 1978. The effects of dikegulac on azalea cuttings. MS Thesis, Univ. of Tennessee, Knoxville.

Scott, L. E., J.H. Mitchell, and R.A. McGinty. 1939. Effects of certain treatments on the carbohydrate reserves of asparagus crowns. South Carolina Agr. Expt. Sta. Bul. 321.

Shelton, D.R. and M.L. Lacy. 1980. Effect of harvest duration on yield and depletion of storage carbohydrates in asparagus roots. J. Amer. Soc. Hort. Sci. 105:332-335. 